\title{
Non Sibi, Sed Omnibus: Influence of Supplier Collective Behaviour on Corporate Social Responsibility in the Bangladeshi Apparel Supply Chain
}

\author{
Enrico Fontana ${ }^{1}$ (D) Niklas Egels-Zandén ${ }^{2}$
}

Received: 4 October 2017 / Accepted: 16 February 2018 / Published online: 23 February 2018

(c) The Author(s) 2018. This article is an open access publication

\begin{abstract}
Local supplier corporate social responsibility (CSR) in developing countries represents a powerful tool to improve labour conditions. This paper pursues an inter-organizational network approach to the global value chain (GVC) literature to understand the influence of suppliers' collective behaviour on their CSR engagement. This exploratory study of 30 export-oriented and first-tier apparel suppliers in Bangladesh, a developing country, makes three relevant contributions to GVC scholarship. First, we show that suppliers are interlinked in a horizontal network that restricts unilateral CSR engagement. This is justified in that unilateral CSR engagement is a source of heterogeneity in labour practices; consequently, it triggers worker unrest. Second, we present and discuss an exploratory framework based on four scenarios of how suppliers currently engage in CSR given their network's pressure toward collective behaviour: unofficial CSR engagement, geographic isolation, size and competitive differentiation, and external pressure. Finally, we show the need to spread CSR homogeneously among suppliers and to reconceptualize the meaning of CSR in developing countries, encouraging more scrutiny toward horizontal dynamics.
\end{abstract}

Keywords Corporate social responsibility $\cdot$ Global value chains $\cdot$ Supplier network $\cdot$ Collective behaviour · Developing countries $\cdot$ Bangladeshi apparel supply chain

$\begin{array}{ll}\text { Abbreviations } \\ \text { CSR } & \text { Corporate social responsibility } \\ \text { BGMEA } & \begin{array}{l}\text { Bangladesh Garment Manufacturers and } \\ \text { Exporters Association }\end{array} \\ \text { BKMEA } & \begin{array}{l}\text { Bangladesh Knit Manufacturers and Exporters } \\ \text { Association }\end{array} \\ \text { GVCs } & \begin{array}{l}\text { Global value chains } \\ \text { G }\end{array}\end{array}$

Enrico Fontana

enrico.fontana@phdstudent.hhs.se

Niklas Egels-Zandén

niklas.zanden@gu.se

1 Department of Marketing and Strategy, Stockholm School of Economics, Sveavägen 65, 11383 Stockholm, Sweden

2 Department of Business Administration, School of Business, Economics and Law, University of Gothenburg, Vasagatan 1, 41124 Gothenburg, Sweden

\section{Introduction}

Although the literature highlights multiple drivers behind corporate social responsibility (CSR) engagement in global value chains (GVCs) (e.g. Gereffi et al. 2005; Lund-Thomsen and Lindgreen 2014), poor labour conditions in developing countries remain a major concern (Brammer et al. 2011). Local suppliers, in particular, play a pivotal role in improving labour conditions through their own CSR (Perez-Batres et al. 2012; Reed 2002; Yawar and Seuring 2017). This is thanks to their ability to aggregate capital (Naeem and Welford 2009; Welford and Frost 2006), and to replace, or complement, weak local or national governments (Mair et al. 2012; Rahim 2017; Visser 2008).

Despite the importance of suppliers, there is limited research on their CSR engagement ${ }^{1}$ in general (Lund-Thomsen and Lindgreen 2014; Yawar and Seuring 2017), and particularly on how horizontal dynamics shape their CSR engagement. Differently from vertical chains, defined as 'the trail of products upstream to sites of production' (Neilson

\footnotetext{
${ }^{1}$ For notable exceptions on South Asian apparel suppliers, see Jayasinghe (2016) for Sri Lanka, Soundararajan and Brown (2016) for India, Fontana (2017) and Huq et al. (2014) for Bangladesh.
} 
and Pritchard 2010, p. 1834), horizontal dynamics represent the interlinked and contextual relations among suppliers in the same industry (Posthuma and Nathan 2010). They are significant because they govern suppliers' relationship with each other (Niforou 2015). This lack of scrutiny is problematic, since such horizontal influence is increasingly recognized as central to understanding labour conditions in GVCs (Lund-Thomsen and Coe 2015; Niforou 2015).

Drawing on the inter-organizational network literature, we advocate examining suppliers as part of horizontal networks of collective behaviour. In so doing, we respond to recent calls to consider horizontal influences in GVCs (e.g. Niforou 2015), while also embracing the Santana et al. (2009) call to better explain CSR engagement by examining networked dynamics among business actors. We advance understanding of CSR engagement in GVCs by pursuing two research questions:

1. What is the effect of suppliers' collective behaviour on their own individual CSR engagement?

2. How can CSR engagement be increased among suppliers in the apparel industry of a developing country context?

Empirically, we draw on in-depth and explorative fieldwork on 30 first-tier, export-oriented apparel suppliers in Bangladesh. The apparel industry in the GVC literature is archetypal due to its implications for labour' rights (Giuliani 2016; Merk 2014). More specifically, Bangladesh symbolizes a fundamental area of scrutiny, in light of scathing criticism of its poor labour conditions (Belal and Roberts 2010; Huq et al. 2014; Rahim 2017) and in parallel with its undisputed importance as an apparel industry supplier (Fontana 2017).

We make three main contributions to the GVC literature. First, we show that suppliers in developing countries belong to a horizontal network which can, through normative pressure, lead to pursuit of collective behaviour aimed at preventing unilateral CSR engagement and labour unrest. Conceptually, we contend that studies on labour conditions in GVCs have relied too much on a vertical paradigm and fail to consider the influence of this horizontal network. The network represents a shared social resource for suppliers and a mechanism for industry-wide governance.

Second, we set forth an exploratory framework entailing four scenarios for when CSR engagement is possible: when suppliers (1) do it unofficially, (2) do it in isolation, (3) are larger in size and force their network to embrace it, and (4) acquiesce to external actors, such as buyers and trade associations. Third, we advocate ensuring CSR engagement homogeneously in the network. This is achievable by creating awareness through wider circulation of information on CSR benefits, in conjunction with reconceptualizing the meaning of CSR engagement in developing countries in light of the need to consider horizontal dynamics and sociocultural variables.

In particular, we define CSR as those discretionary corporate practices that engender social benefits for the labour force and the local community, beyond compliance to standard certifications and imposed codes of conduct (Jayasinghe 2016; McWilliams and Siegel 2001).

This can be constituted by workers' higher financial benefits that are not compulsory by law, such as wages and/or insurance, but also extra facilities for the workers, such as free of charge canteens and special incentives.

Our focus thus differs from the common focus on private regulation and the GVC literature, which generally equates CSR engagement to (private) regulatory compliance (LundThomsen and Lindgreen 2014; Sharmin et al. 2014; Yawar and Seuring 2017).

The remainder of this paper proceeds as follows. First, we present the theoretical background. After an overview of drivers of supplier CSR engagement in GVCs, we incorporate the inter-organizational network viewpoint of the GVC literature to justify expansion of collective behaviour in supplier networks. Second, we provide a descriptive account of Bangladesh as our research context. Third, we present our methodology, elaborating on our research design, theoretical sampling and data analysis. Fourth, we unveil our findings, then discuss our main contributions to the GVC literature, including recommendations on CSR engagement in developing countries. Finally, we present concluding remarks, with attention to the paper's limitations and suggestions for future research.

\section{Theoretical Background}

\section{Drivers of Supplier CSR Engagement in GVCs}

Supplier CSR engagement in developing countries is often viewed as a by-product of external pressures (Gereffi 1994; Lund-Thomsen and Lindgreen 2014; Rahim 2017), especially from buyers' vertical impositions (Acquier et al. 2017; Foerstl et al. 2015; Gereffi et al. 2005; Ponte and Gibbon 2006). However, the GVC literature shows that CSR engagement can generate market advantages (e.g. Gereffi et al. 2005) in addition to their being undertaken for ethical reasons (e.g. Bansal and Roth 2000).

CSR engagement is presented as bringing advantages in dealing with buyers and reducing suppliers' power asymmetry (Hoejmose et al. 2013). By actively engaging in CSR, suppliers are more likely to nurture buyer trust, strengthening the relationship (Aßländer et al. 2016; Pagell and Wu 2009). Roberts (2003), for instance, postulates that apparel suppliers can exploit CSR engagement as a vehicle to glean buyer approval. Likewise, active CSR engagement allows 
suppliers to gain a stronger reputation in the market, attracting potential customers (Brammer et al. 2011; Hoejmose et al. 2014).

Further, CSR engagement can attract skilled labour (Greening and Turban 2000). CSR engagement in developing countries has been studied for its positive effect on employee motivation (Jayasinghe 2016), helping local manufacturers consolidate their reputations within local communities (Jamali and Mirshak 2007). This is particularly important in apparel GVCs, where suppliers face continuous struggles to overcome shortages of skilled employees (Fernandez-Stark et al. 2011; Jayasinghe 2016).

In addition, it is argued that CSR engagement is a tool for innovation thanks to improved operational performance (Pagell and Wu 2009). Fontana (2017) studies Bangladeshi executives in apparel GVCs and demonstrates that CSR engagement leads to strategic value when associated with functional upgrading. In a similar vein, Foerstl et al. (2015) highlight that suppliers can increase their competitiveness when integrating CSR with their product offerings.

However, much less scrutinized in the GVC literature are the reasons behind lack of CSR engagement among suppliers. Neilson and Pritchard (2010) set forth a critical counterargument of the vertical paradigm of CSR. These authors underscore that supplier CSR engagement coordinated by buyers is in conflict with regional norms, underlining the weak scrutiny of suppliers' horizontal behaviour. There exists, in fact, little recognition of the horizontal dimension in developing countries, especially with regard to the influence of suppliers on each other (Lund-Thomsen and Coe 2015; Neilson and Pritchard 2010; Niforou 2015).

\section{A Network Perspective of Supplier Behaviour in GVCs}

Pursuant to inter-organizational network scholarship, firms are interconnected in networks, linked horizontally by social ties (Astley and Fombrun 1983; Borgatti and Foster 2003). These ties have been long scrutinized under a sociological and structuralist viewpoint due to their influence on corporate decision-making, explaining divergence with rational market theory (Granovetter 1985). A network's strength inheres in its constituents' ability to coordinate and take joint decisions (Borgatti and Foster 2003). Firms participate in their networks by pursuing collective behaviour and cooperating, as opposed to acting unilaterally and self-interestedly (Håkansson and Johanson 1988). Collective behaviour represents a self-organized business governance mechanism that replaces third-party intervention and aims to benefit constituents (Börzel and Risse 2010).

Suppliers' collective behaviour in the GVC literature has been studied with particular reference to developing countries' industrial clusters, stressing its importance in gaining inter-organizational trust (Knorringa and Nadvi 2016), and as system of social relations (Schmitz and Nadvi 1999). Schmitz (1999), for instance, introduces the notion of collective efficiency as a by-product of collective behaviour, driving competitive advantage among developing country suppliers. In contrast, unilateral action amounts to ethical misconduct when it alters negatively the inter-organizational environment (Melé 2009).

The implications of collective behaviour in the GVC literature, however, are studied mainly with respect to economic payoffs rather their effect on labour conditions (Gereffi and Lee 2016; Nadvi 1999). It is, thus, interesting to extend these findings beyond economic payoffs into the realm of CSR engagement.

As derived by inter-organizational network scholarship, three conditions can encourage collective behaviour in the network: (1) high corporate density, (2) social norms and (3) shared resources.

\section{Density, Norms and Shared Resources as Drivers of Collective Behaviour}

Density represents the number of social ties linking network constituents. Sociologists have observed that dense inter-organizational networks favour collective behaviour because of individual constituents' effect on decision-making (Marwell et al. 1988). Due to interdependency, dense networks make independent and deviant behaviours more easily detectable (Coleman 1988), increasing vulnerability and turbulence (Astley and Fombrun 1983). Hence, network organization scholars have studied density as a vehicle for inter-firm cooperation and benefits (Munksgaard and Medlin 2014).

Although there exists several viewpoints that oppositely defines network density, especially in the cluster literature (e.g. Lund-Thomsen et al. 2016), in the GVC literature, density equals geographic proximity. According to Gereffi et al. (2005), geographic proximity increases transactions among suppliers and enhances collective behaviour. Proximity has been theorized as nurturing a cluster effect and economic development (Schmitz and Nadvi 1999), which comprises corporate performance and recovery (Rabellotti 1999), competitiveness (Nadvi 1999) and cooperation (Knorringa and Nadvi 2016; Lund-Thomsen and Nadvi 2010).

Further, actors' collective behaviour is influenced by social norms, which hinge on local traditions and beliefs shared among network constituents (Frost and Egri 1991), perceivable during tacit arrangements (Astley and Fombrun 1983). Social norms allow network constituents to collectively regulate themselves (Cialdini and Trost 1998; Granovetter 1985) and to share their obligations (Coleman 1988). Social norms take form of normative pressure toward collective behaviour and alignment, including CSR engagement 
(Neville and Menguc 2006; Santana et al. 2009). According to Gould (1993) for example, networked businesses fear being ostracized and avoid unilateral action if this harms their peers. Likewise, both Frost and Egri (1991) and Elg and Johansson (1997) contend that social norms can be used to ensure collective behaviour in the network by presenting the status quo as inviolable.

The GVC literature shows that social norms differ in accordance with geographic location or social group (Gereffi et al. 2005), and that they are central in governing relationships in developing countries (Jamali and Karam 2016; Muthuri et al. 2009). On the positive side, social norms are inherently fair and reciprocal, antecedent to CSR engagement and ethical behaviour (Millar and Choi 2009). Generally, they limit unilateral action when this is perceived as harmful to other network constituents, imposing fear of retaliation (Melé 2009). Social norms are often traceable to religious roots, especially in the developing world. Pursuant to Williams and Zinkin (2009), social norms in predominantly Muslim countries determine societal commitment, since Islamic religious instructions per se exceed the international guidelines advanced by the United Nations Global Compact pillars. The Zakat, for instance, requires firms to donate, annually, $2.5 \%$ of their net profit to the poor, even though the proofs of these payments remain unregistered and hardly assessable (Jamali et al. 2009). Jamali's (2007) example of business-sponsored art festivals in Lebanon demonstrates that CSR engagement has strong philanthropic roots.

Social norms can also limit CSR engagement. Mezzadri (2014) demonstrates that community relations in developing countries may be rooted in secular structures of power and patronage. Giuliani's (2016) link of community-wide behaviour to cultural relativism explains that ethnic values may lead firms astray from CSR engagement. Likewise, the interpretation of ethics among Muslims varies, leading to different behaviours vis-à-vis CSR engagement (Williams and Zinkin 2009).

Third, much of the inter-organizational network literature scrutinizes a network's collective behaviour stemming from shared resources (Elg and Johansson 1997; Munksgaard and Medlin 2014). Munksgaard and Medlin (2014) pinpoint that sharing resources boosts a 'network effect' which yields greater value than what a firm alone would create, benefitting all parties. Pursuant to this viewpoint, acting collectively fosters relationships and enhances bestpractice performance (Daboub and Calton 2002).

The Davies (2009) example of collaboration among fair trade producers in GVCs demonstrates that sharable resources motivate collective behaviour. There are numerous shared resources. Labour, for instance, has attracted much attention in GVCs. Welford and Frost (2006) portray the case of developing country workers who migrate from remote areas to industrial areas to seek employment. They are shared from one factory to another, with the hope of increasing their salary and skills. Other shared resources include the value of social relations for innovation (Gereffi and Lee 2016; Nadvi 1999) and information exchange (Rabellotti 1999). Shared knowledge through information exchange, in particular, increases awareness about others' decision-making in the network, favouring collective behaviour and potentially leading to a wider understanding of ethics (Millar and Choi 2009). In sum, density, social norms and shared resources encourage collective behaviour, depending on the context.

\section{Bangladesh as Research Setting}

Bangladesh is a developing country, inhabited by a predominantly Muslim population of 152.1 million in a limited area of $146,460 \mathrm{~km}^{2}$ (CIA 2016). Bangladesh acquired its independence from Britain in 1947 but gained full freedom only in 1971 after the liberation war with Pakistan (Belal and Roberts 2010). Albeit reaching the UN Medium Human Development Category, 75.6 million Bangladeshis (49.5\% of its population) live under the multidimensional poverty bar, which includes income, schooling and access to potable water (UNDP 2015). Bangladesh remains the least developed country in South Asia (Rahim and Alam 2014; Siddiqui 2010), characterized by a traditional society where political power is retained in the hands of a few families and a limited capitalist class (Uddin and Choudhury 2008). Most Bangladeshi firms are family-owned (Siddiqui 2010), control the country's media (Rahim 2017) and are weakly regulated (Mair et al. 2012).

Fieldwork with local executives in Bangladesh's apparel supply chain (Fontana 2017) and corporate surveys (Naeem and Welford 2009) corroborate the increasing attention on CSR engagement. On the other hand, Bangladeshi firms' self-regulation and lack of formal disclosure are accused of facilitating evasion of CSR (Belal and Roberts 2010; Rahim 2017). Despite its market advantages (Fontana 2017), CSR engagement in the Bangladeshi apparel industry is conventionally attributed to pressure from foreign markets (Belal and Roberts 2010), mainly international buyers (Islam and Deegan 2008).

Although social norms in Bangladesh are often overlooked by international buyers (Belal and Roberts 2010; Reed 2002), they are attributable to Muslim teaching. This drives a de facto informal and philanthropic type of CSR engagement.

\section{The Bangladeshi Apparel Supply Chain}

The Bangladeshi apparel supply chain is well-suited for CSR studies due to its continuous labour problems and need for social improvement (Soundararajan and Brown 
2016). Bangladesh is today preferred by $81 \%$ of international apparel buyers due to its production capabilities and low prices (BGMEA 2016a). However, its 4 million apparel workers face difficult issues, such as gender inequality, child labour, lack of representation (ILO 2015a; Labowitz and Baumann-Pauly 2015; Naeem and Welford 2009) and grievances driven by their migrant backgrounds (Welford and Frost 2006).

Poor health and safety measures account for the lion's share of criticism, particularly after the Rana Plaza cataclysm in 2013 (ILO 2015b; Rahim 2017). As wages remain among the lowest worldwide (Siddiqui 2010), foreign-led initiatives to improve labour conditions have seen a recent upsurge (Berg et al. 2011, 2013; Needham 2015). These are supported by the Bangladesh Garment Manufacturers and Exporters Association (BGMEA) and Bangladesh Knit Manufacturers and Exporters Association (BKMEA). These two organizations hold the ability to politically influence labour practices (Islam and Deegan 2008) and have an active role in promoting CSR engagement in Bangladesh.

\section{Research Methodology}

\section{Research Design}

This paper adopts a qualitative and interpretative approach, as suits scrutiny of organizational phenomena such as CSR engagement (Bluhm et al. 2011). Primary data for the empirical analysis were collected in two rounds, in August 2015 and August 2016. The fieldwork amounted to 32 in-depth, open-ended and semi-structured interviews administered with 30 suppliers (Table 1), completed by the first author of this paper. Fieldwork in 'hybrid' postcolonial contexts such as Bangladesh comprises personalities with diverse attitudes, behaviours (Angrosino and Rosenberg 2011) and understanding of business ethics (Liedtka 1992), increasing the need for face-to-face discussions. Although respondent job titles are reported, suppliers are assigned numbers to guarantee corporate anonymity.

Although only two interviews with suppliers from August 2015 were ultimately added to the sample, this first fieldwork served to test the cogency of the interview protocol and the feasibility of the study. The importance of conducting preliminary research is justified by the "messy and episodic' journey that characterizes qualitative data collection (Eisenhardt et al. 2016), including a reflexive account and the unfolding of real-time situations (Bluhm et al. 2011). The bulk of data were gathered throughout August 2016, with 30 interviews executed for 28 firms. Because there are no official and comprehensive indicators of CSR measurement (Yawar and Seuring 2017), and since top managers in apparel GVCs hold decision-making power over CSR engagement (Park and Stoel 2005), only the top management of each supplier firm was selected for the interviews. These managers were often interviewed in pairs, with one or two additional managers, providing a good balance between small group and individual context (Ritchie et al. 2013). One interview included a former BGMEA president (BGMEA 2016a) and owner of one of the firms in the sample. All interviews were conducted in English. Table 1 lists all suppliers and gives their (1) size, (2) managers interviewed, (3) location, (4) group belongingness (whether they are a unit of a larger group), (5) production and (6) geographic isolation (suppliers with at least $20 \mathrm{~km}$ distance from any other apparel supplier).

\section{Theoretical Sampling}

Approximately 78 independent suppliers were identified in spring 2016 and contacted first via e-mail, then telephone. Although acquiring the contacts was facilitated by the support of local personnel in Bangladesh, reaching all potential interviewees required approximately two months. Twenty-eight suppliers ultimately accepted a visit and sat for an interview (35.8\% response rate), in addition to the two suppliers already interviewed in August 2015. Pursuant to theoretical sampling (Eisenhardt et al. 2016), supplier appraisal for the purpose of sample building was subjected to rigorous criteria. By virtue of the selected CSR definition as 'beyond compliance', the 78 independent suppliers identified must first be included in the list of the Accord, and their first contact information was retrieved from the Accord's list. The Accord is a multistakeholder organization that ensures compliance with health and safety standards, incorporated following the Rana Plaza disaster (Accord 2016a). The publicly available Accord lists all suppliers scrutinized and those that had already reached compliance (Accord 2016b).

Further, due to the fact that CSR engagement is often observed in large firms (Visser 2008), supplier selection must fit a wider size-continuum. This increases the sample's representativeness and depth of insight. The final sample comprises suppliers ranging from 300 to $10,000+$ employees. In addition, it is very important to ascertain reachability. Out of the final 30 suppliers that accepted to be interviewed, 26 factory premises were visited in situ, mostly located in Upazilas (sub-regions) requiring on average 2-4-h car drive from Dhaka city. Direct observance of facilities adds veracity to the interview material. Only four supplier representatives were interviewed in their Dhaka offices, given the difficulty of reaching their facilities.

Finally, all suppliers must be first-tier (selling to international buyers) and have an export license, which in Bangladesh requires membership in BGMEA and/or BKMEA (BGMEA 2016b; BKMEA 2016). 
Table 1 Suppliers' sample

\begin{tabular}{|c|c|c|c|c|c|c|}
\hline Sample \# & Size & Interviewees & Upazila & Part of group & Product & $\begin{array}{l}\text { Geo- } \\
\text { graphical } \\
\text { isolation }\end{array}$ \\
\hline Firm 1 & 300 & (1) HR Manager & Narayangonj Sadar & Yes & Knit & No \\
\hline Firm 2 & 370 & $\begin{array}{l}\text { (1) General Manager } \\
\text { (2) Assistant General Manager Merchandising }\end{array}$ & Narayangonj Sadar & No & Knit & No \\
\hline Firm 3 & 424 & (1) Chief Executive & Dhaka city & No & Woven & No \\
\hline Firm 4 & 500 & (1) Deputy Managing Director & Narayangonj Sadar & No & Knit & No \\
\hline Firm 5 & 500 & $\begin{array}{l}\text { (1) Owner } \\
\text { (2) General Administrator }\end{array}$ & Savar & Yes & Sweater & No \\
\hline Firm 6 & 564 & $\begin{array}{l}\text { (1) Chief Manager Accounts and Finance } \\
\text { (2) General Manager }\end{array}$ & Savar & No & Knit & Yes \\
\hline Firm 7 & 600 & $\begin{array}{l}\text { (1) Senior Merchandiser (2) Manager HR and Compli- } \\
\text { ance }\end{array}$ & Narayangonj Sadar & No & Knit & No \\
\hline Firm 8 & 700 & (1) Executive Director & Narayangonj Sadar & No & Knit & No \\
\hline Firm 9 & 800 & $\begin{array}{l}\text { (1) General Manager } \\
\text { (2) Manager HR and Compliance }\end{array}$ & Narayangonj Sadar & No & Knit & Yes \\
\hline Firm 10 & 800 & $\begin{array}{l}\text { (1) Owner (2) Owner's son (3) Manager HR and Com- } \\
\text { pliance }\end{array}$ & Gazipur Sadar & No & Knit & No \\
\hline Firm 11 & 1000 & (1) Executive Director (2) Compliance Manager & Kaliakair & Yes & Under-garments & No \\
\hline Firm 12 & 1200 & (1) Chief Executive Officer & Narayangonj Sadar & No & Woven & No \\
\hline Firm 13 & 1408 & (1) General Manager & Savar & Yes & Woven & No \\
\hline Firm 14 & 1600 & (1) Owner & Gazipur Sadar & No & Knit & No \\
\hline Firm 15 & 1700 & (1) Director of Administration & Savar & Yes & Knit & No \\
\hline Firm 16 & 1800 & (1) Owner & Kaliakair & Yes & Knit & No \\
\hline Firm 17 & 1900 & $\begin{array}{l}\text { (1) Executive Director Operation and Corporate Share- } \\
\text { holder (2) Project Director }\end{array}$ & Kaliakair & Yes & Knit & No \\
\hline Firm 18 & 2000 & (1) Manager HR and Compliance & Gazipur Sadar & Yes & Sweater & Yes \\
\hline Firm 19 & 2500 & (1) Executive Director & Ishwardi & Yes & Denim & No \\
\hline Firm 20 & 2700 & (1) Manager HR and Compliance & Savar & Yes & Woven & No \\
\hline Firm 21 & 2800 & $\begin{array}{l}\text { (1) Manager HR and Admin (2) Senior Manager } \\
\text { Compliance }\end{array}$ & Gazipur Sadar & Yes & Knit & Yes \\
\hline Firm 22 & 3500 & $\begin{array}{l}\text { (1) Assistant General Manager of Merchandising (2) } \\
\text { Deputy General Manager Marketing and Merchandis- } \\
\text { ing (3) Senior Executive Banking and Purchase }\end{array}$ & Savar & Yes & Sweater & No \\
\hline Firm 23 & 4000 & (1) General Manager Administration and Compliance & Savar & Yes & Woven and Knit & No \\
\hline Firm 24 & 5000 & (1) Executive Director & Savar & Yes & Woven and Knit & No \\
\hline Firm 25 & 5500 & $\begin{array}{l}\text { (1) Manager HR, Compliance and Admin (2) Head of } \\
\text { Marketing and Merchandising }\end{array}$ & Kaliakair & Yes & Knit & No \\
\hline Firm 26 & 5500 & (1) Senior Manager Finance and Accounts & Narayangonj Sadar & Yes & Woven & No \\
\hline Firm 27 & 6000 & $\begin{array}{l}\text { (1) Senior Manager System and Process Director (2) } \\
\text { Manager Safety and Admin (3) General Director (4) } \\
\text { Owner }\end{array}$ & Savar & Yes & Woven and Knit & No \\
\hline Firm 28 & 7000 & $\begin{array}{l}\text { (1) Engineering Head (2) Manager Utility (3) Assistant } \\
\text { General Manager Compliance }\end{array}$ & Saturia & Yes & Woven & Yes \\
\hline Firm 29 & $10,000+$ & (1) Executive Director & Narayangonj Sadar & No & Knit & No \\
\hline Firm 30 & $10,000+$ & $\begin{array}{l}\text { (1) Head of Sustainability (2) Senior Executive Sustain- } \\
\text { ability }\end{array}$ & Gazipur Sadar & Yes & Knit & No \\
\hline
\end{tabular}

\section{Data Analysis}

Interviews were recorded, transcribed, systematically examined and coded. Each interview lasted between 40 and $150 \mathrm{~min}$, with an average of $85 \mathrm{~min}$ (excluding time for factory observations). Interviews accrued to over 175,000 transcribed words. Coding was operationalized through a two-way procedure. First, it was manually executed after 
Table 2 Data structure of aggregate and 2nd order themes

\begin{tabular}{|c|c|}
\hline Codes & Description \\
\hline Aggregate theme A-Collective Behaviour & $\begin{array}{l}\text { Suppliers are network constituents and pursue a collective behaviour vis-à-vis CSR engagement. } \\
\text { However, their collective behaviour discourages unilateral CSR engagement due to heterogeneity } \\
\text { and the risk of workers' unrest }\end{array}$ \\
\hline (1) Network & $\begin{array}{l}\text { Suppliers are constituent part of a network of social relationships that provides help and reciprocal } \\
\text { support }\end{array}$ \\
\hline (2) Unilateral CSR engagement & $\begin{array}{l}\text { Unilateral CSR engagement is perceived to yield to heterogeneity of labour practices, ultimately } \\
\text { creating turbulence in the networks through workers' unrest }\end{array}$ \\
\hline (3) Normative pressure & $\begin{array}{l}\text { Suppliers' collective behaviour on CSR engagement is enforced through normative pressure among } \\
\text { suppliers }\end{array}$ \\
\hline (4) CSR information & $\begin{array}{l}\text { Suppliers' CSR engagement is easily detectable as its information is shared through direct (among } \\
\text { suppliers) and indirect (workers' word-of-mouth) communication }\end{array}$ \\
\hline Aggregate theme B -CSR engagement & $\begin{array}{l}\text { Suppliers engage in CSR by (1) doing it unofficially, (2) doing it in isolation, (3) being larger in size } \\
\text { and imposing it on others (4) by following external actors, such as buyers and trade associations }\end{array}$ \\
\hline (5) Unofficial CSR engagement & $\begin{array}{l}\text { Suppliers can engage in CSR if unofficial and unrecognized. However, this conveys only limited } \\
\text { benefits. Religious-driven social norms play a fundamental role against public divulgate CSR } \\
\text { information }\end{array}$ \\
\hline (6) Geographical isolation & $\begin{array}{l}\text { Geographically isolated suppliers are less impacted by the collective behaviour of network's constit- } \\
\text { uents than those suppliers sharing boundaries with other apparel factories }\end{array}$ \\
\hline (7) Size and competitive differentiation & $\begin{array}{l}\text { The larger suppliers are in size, the less they are impacted by the network's collective behaviour and } \\
\text { the more they see CSR engagement as source for competitive differentiation. However, this drives } \\
\text { a tension, as CSR engagement force surrounding suppliers to apply it }\end{array}$ \\
\hline (8) External pressure & $\begin{array}{l}\text { CSR engagement can be encouraged by buyers and industry associations (BGMEA/BKMEA). } \\
\text { However, both buyers and industry associations need to ensure that CSR's homogeneous engage- } \\
\text { ment }\end{array}$ \\
\hline
\end{tabular}

completion of each transcript, singling out text segments within a separate Excel file. While using the gleaned data to refine and finalize code selection, each transcript went through an additional process of iterative proofreading, followed by final digital coding using Nvivo, a qualitative data analysis computer software package.

In line with the Gioia et al. (2013) method, the coding process was divided into three critical steps. First, the interviews produced approximately 50 first-order categories of open codes, broad and unidentified. These codes label indicative phenomena, such as 'providing support during crisis', 'community feeling' or 'fear of neighbour's reaction'. Second, a process of axial coding grouped the 50 first-order categories into $8 \mathrm{~s}$-order themes. This allowed grouping and explaining the phenomena theoretically. Third, two aggregate dimensions were created comprising the eight secondorder themes. The second-order themes and aggregated dimensions are outlined in Table 2.

\section{Data Triangulation}

As confirmatory analysis, transcribed interviews were triangulated with 1) more than 20,000 words of documented observations executed in situ at each factory visited, comprising memorandum material and reflective writings on individual interactions with interviewees, and 2) secondary online data. Triangulation not only allows for greater data reliability and construct validity (Bluhm et al. 2011), itself substantiating the grounding of emergent theories (Eisenhardt 1989), but also allows checking for social desirability bias during interviews, whose likelihood is higher for sensitive arguments exposed in local contexts (Zerbe and Paulhus 1987). Notes and observations were compiled immediately after each interview, illuminating the empathic views of interlocutors who are part of the suppliers' network under examination (Angrosino and Rosenberg 2011).

With reference to secondary online data, 21 of 30 suppliers $(70 \%)$ had their own corporate websites, 5 suppliers (16.7\%) had a page dedicated to social activities in general, with only 2 suppliers (6.7\%) providing in-depth information on CSR engagement for their workers. These data served two important functions. First, it completed suppliers' standard information, acting as an indicator of plausible divergence from what was presented offline, in line with Angrosino and Rosenberg (2011). Second, it provided useful information for the creation of aggregate theme B, with particular reference to second-order themes 5 and 7.

\section{Findings}

Our findings are presented in two sections. The first sheds light on suppliers' collective behaviour toward CSR engagement. This is applied in Bangladesh to ensure labour practice homogeneity among suppliers, discouraging unilateral CSR 
Table 3 Size-driven CSR engaging behaviour among suppliers

\begin{tabular}{lrcccc}
\hline Supplier Size & N & Alignment with others & Official CSR & $\begin{array}{l}\text { CSR believed to } \\
\text { yield unrest }\end{array}$ & $\begin{array}{l}\text { CSR per- } \\
\text { ceived as } \\
\text { strategic }\end{array}$ \\
\hline$<1000$ & 10 & $10(100 \%)$ & 0 & $8(80 \%)$ & $3(30 \%)$ \\
$1000-1999$ & 7 & $6(85.7 \%)$ & $1(14.3 \%)$ & $7(100 \%)$ & $3(42.8 \%)$ \\
$2000-5000$ & 7 & $5(71.4 \%)$ & $2(28.6 \%)$ & $5(71.4 \%)$ & $3(42.8 \%)$ \\
$>5000$ & 6 & $1(16.7 \%)$ & $5(83.3 \%)$ & $4(66.7 \%)$ & $5(83.3 \%)$ \\
TOT & 30 & $22(73.3 \%)$ & $8(26.7 \%)$ & $24(80 \%)$ & $14(46.6 \%)$ \\
\hline
\end{tabular}

engagement through normative pressure, including direct (through communication among suppliers) and indirect (through workers' word-of-mouth) flows of CSR information. The second section presents an exploratory framework based on four scenarios for CSR engagement. Table 3 shows a summary of supplier behaviour vis-à-vis CSR engagement, analysed by size.

\section{Horizontal Effect of Suppliers' Collective Behaviour on CSR Engagement}

In terms of our first research question, the first findings show that Bangladeshi suppliers constitute part of a horizontal network in which they behave collectively, nurturing cooperation and trust through social relationships. Their cooperation is justified by the need to secure friendly and durable relationships within their networks. Surprisingly, we find that collective behaviour prevents suppliers from unilaterally engaging in CSR, promoting homogeneous labour practices through normative pressure.

In the sample, 22 suppliers (73.3\%) confirmed behaving collectively while ensuring their alignment to others' labour practices. In particular, 24 suppliers (80\%) accused unilateral CSR engagement of de facto igniting a climate of worker unrest and boycotts in surrounding factories, potentially destabilizing the entire network; they attributed this to labour practice heterogeneity among suppliers. CSR as a unilateral engagement was believed to coerce all surrounding factories to apply the same practices. The inability to similarly engage in CSR would result in having to close these factories. The quote below exemplifies the perceived danger arising from unilateral CSR engagement in the network, such as providing free lunch as an extra benefit.

Of course. If you, for instance, pay lunches and nobody else does...that is a problem. Don't do it. You have to adapt to the society [...]. Because then if anything happens [to the network], who will be responsible for that? (Owner, Firm 27)

Table 4 presents nine additional quotes from various corporate representatives, defining 'the perils' of unilateral CSR engagement.
Our findings also reveal that information on supplier CSR engagement is shared because of direct and indirect communication, limiting deviance from collective behaviour. Twenty-seven (90\%) suppliers admitted to being directly in touch with each other and periodically sharing information on their labour practices. This ensured alignment and collective behaviour, as detailed by two interviewees:

We talk about how to share issues. Say, for instance, before Eid holiday. We sit together and discuss with them concerning who will be giving 6 days leave, 8 days leave, 10 days leave and when we will pay the benefits, bonus, fixed amounts. So, if we set up all same benefits, bonus and fixed days, nobody will create any problem (Director of Administration, Firm 15)

Since communication is easy, we communicate with the factories around [...]. Sometimes I call our colleagues and ask what is their practice, or how is the planning of their Eid, next month. I might ask them how many days they are going to give [to their workers] (General Manager Administration and Compliance, Firm 23)

In addition, our findings suggest that suppliers are indirectly connected through their workers. Workers live together and share the same facilities, as described by Welford and Frost (2006), but also rotate jobs among factories, spreading information about working conditions and supplier CSR engagement, mostly within the same geographic area. This creates a fragile situation where it is arguably unlikely for an individual supplier to engage in CSR autonomously while remaining unnoticed, increasing collective behaviour and discouraging unilateral action. As described by two representatives:

You have to mind that among the workers, the younger brother can stay in your factory, and the older brother can stay in my factory. Two friends, one can stay in one factory and another in another factory. At night they sleep together, they walk together, they are in the village together, talking together and playing together. [...] The husband is working in this factory and the wife is working in that factory. At night they are together (Owner, Firm 27) 
Table 4 Quotes illustrating 'the perils' to the network of individually engaging in CSR

Representative quotes

'Maybe if some factories work together and share some ideas...We cannot go only for our factory, because there are so many factories. If we want to add something, there will be pressure on them as well to change. It's a community [...]. If we want to arrange a picnic area it's not possible for each and every factory. Because a lot of factories have no resources to do this' (General Manager, Firm 2)

'We don't like creating problems to others. I suggest to garment factories to not do any CSR. There is here a canteen run by other people, but if it was free... other factories would be affected' (Owner, Firm 3)

'They [factories] are completely aligned to each other and they never think about anything [extra] for the workers because of the surrounding area. What everybody does, they will do the same. [...] They don't think about it. They don't even plan for it. Only if $90 \%$ of the factories do it, then they will do it' (Director and Owner, Firm 5)

'Actually we are afraid to give anything [extra] to the workers. We are just following what others are doing. [...] But nothing extra [...]. We are afraid because this is an industrial area' (Senior Merchandiser, Firm 7)

'At my ex-company they had a very good CSR culture. They [other factories] used to blame our owner: you do too much, you do more than average' (General Manager, Firm 13)

'Let's say you have a factory. You are doing some CSR projects and you are paying also more money [to the workers]. I have one factory. If I want to do business in here I need to apply the same rules as you. Otherwise, how can I handle my workers? They will go to my factory, unrest will be happening in here' (Manager HR and Compliance, Firm 20)

'If I provide lunch here, there are hundreds of other different factories. Maybe they cannot do it. Then there will be unrest. Ok, we are giving it, why is XYZ company not giving? It will become a rule. It will become a demand for them' (Executive Director, Firm 29)

'It is very difficult if I want to do something individually to improve the well-being of the workers. It will be a big issue for the other factories. This is the main problem' (Executive Director Operation and Corporate Shareholder, Firm 17)

'Maybe I can afford [engaging in CSR], but other factories cannot afford. [...]. Here you find that two factories have common boundaries. One factory is next to another factory [...]. That creates problems'

(Senior Manager System and Process Director, Firm 27)

The workers of that factory will visit our factory. Our workers will visit their factory. [...] After 7 or 10 days they will come back again (Manager HR and Admin, Firm 21)

\section{CSR Engagement Among Bangladeshi Suppliers}

With reference to our second research question, our findings suggest four specific scenarios specifying how supplier CSR engagement can be increased in the Bangladeshi apparel industry, disregarding the normative pressure of the network's collective behaviour. As shown by the exploratory framework in Fig. 1, suppliers engage vis-à-vis CSR individually by (1) doing it unofficially, (2) doing it in isolation, (3) being larger in size and imposing it on the network and 4) by acquiescing to external actors, such as buyers and trade associations.

\section{Unofficial CSR Engagement}

By virtue of the network's collective behaviour, only 8 (26.7\%) suppliers engaged in CSR while officially reporting it. All 22 remaining suppliers (73.3\%) admitted to engaging in CSR but unofficially, that is, without divulging it and avoiding exercising influence on others. Only Firm 25 claimed to be engaging in CSR unofficially, however, on a large scale and with the altruistic purpose of influencing others.
Nevertheless, the shortcoming of unofficial CSR engagement is scalability. Suppliers admitted that unofficial CSR engagement allows them to remain unnoticed, but it only allows limited increases in workers' benefits. Unofficial CSR engagement was deemed particularly difficult when addressing considerable increases in workers' wages and extra facilities. Large contributions might lead to unrest because of the indirect communication through workers' word-of-mouth, as instantiated by the quote below.

If it's a small difference maybe it's unnoticed, but a big difference in workers' salaries would create unrest (General Manager Administration and Compliance, Firm 23)

Table 5 displays a summary of five quotes showing unofficial CSR engagement in Bangladesh.

An argument in defence of the high number of suppliers that claimed to engage in CSR unofficially stems from the Muslim roots of Bangladesh, which deeply affect the country's social norms. According to these norms, a strong stigma applies to those who (1) divulge information about their donations and/or (2) do not contribute to religious offerings, comprising donations to the mosque and the poor, as described by Jamali et al. (2009). Arguably, this generates a problem of information authenticity. The Bangladeshi suppliers interviewed declared engaging in CSR as part of their religious principles and social norms. However, it was hard to assess which suppliers really engaged in CSR unofficially due to 


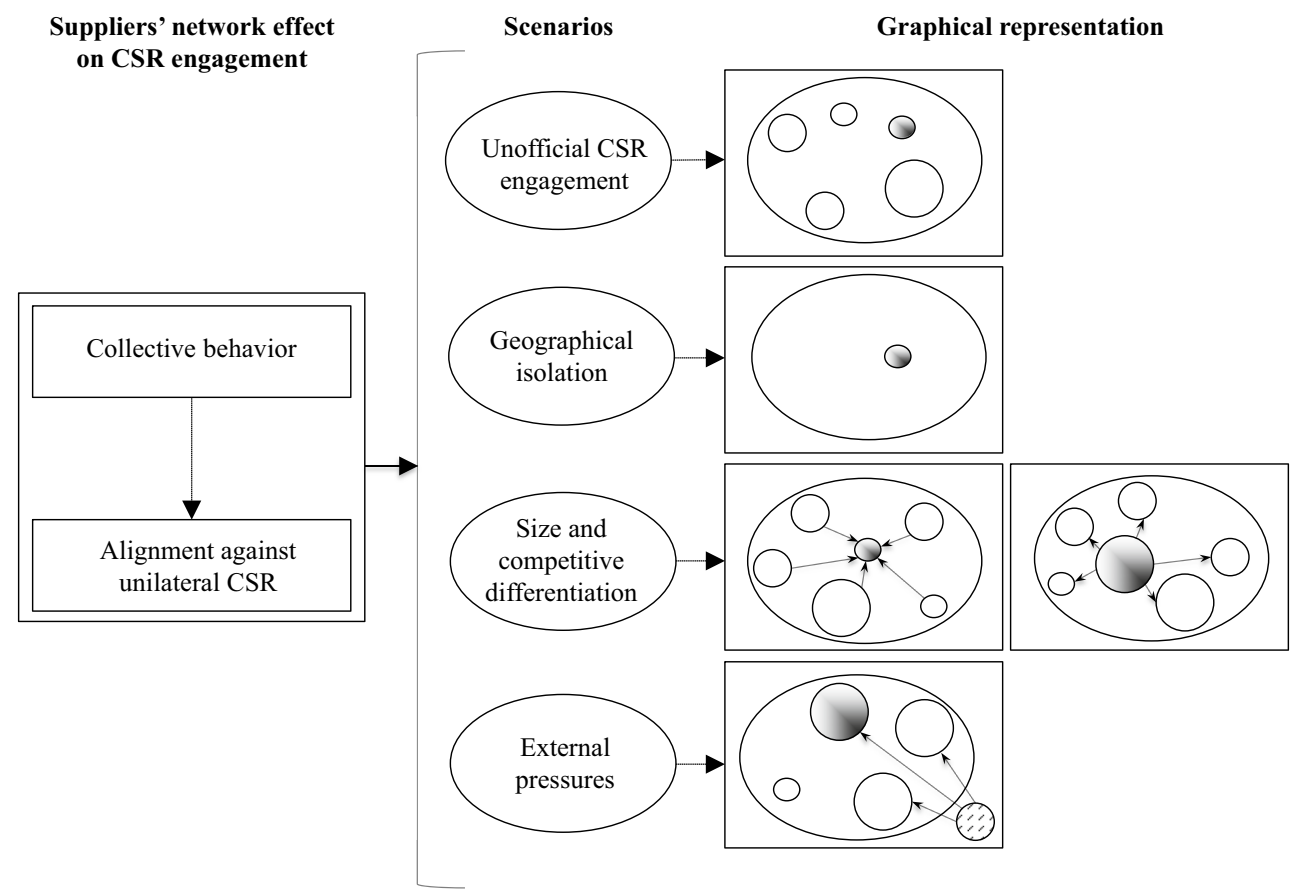

Fig. 1 Supplier CSR engagment in Bangladesh

Table 5 Quotes illustrating unofficial CSR engagement

Representative quotes

'In his home village he is sponsoring a school, he is sponsoring a medical centre. In other parts he is sponsoring a religious teaching school where 100 boys are staying [...]. We are doing it. Everybody is doing it...but you won't find it in our webpage' (Executive Director, Firm 24)

'I am a trustee of a mosque, and also of a madrasa, this means education following the Arabic line. They teach Bengali, mathematics and Arabic. I also pay there, but I never say anyone that I pay this money. [...]. If it's visible, then others will act. If it's not visible, then no, they won't' (Owner, Firm 16)

'Our factory created a primary school, running there. [...] We are giving help yearly. Our workers' children can go there and start school easily. But if we don't help them the school cannot run, the school will be shut down and my workers will go to another place because their children need to go to school. Sometimes buyers ask us why we don't do social work. We say that we do but we don't have the records' (Deputy General Manager Marketing and Merchandising, Firm 22)

'Our workers have no ability to send their son or daughter to school. I pay 20 to 50 people. I pay them always. Nobody knows. Even my son doesn't know. I pay it. But I don't announce it' (General Manager, Firm 9)

'We don't believe in advertisement. But we inspire the other owners to do that [CSR]' (Manager Compliance and Admin, Firm 25)

religion, and which ones exploit religion to avoid engaging in CSR. The quote below confirms the Williams and Zinkin (2009) postulate that Islamic preaching is variably observed, even within the same context.

In Bangladesh most people are growing up in the Muslim way [...]. Someone has more money and engages more in CSR, but some of my close friends [factory owners] are not engaging in any CSR, even unofficially. Someone I know very well. Very close to our relatives. They are not giving any penny to their own staff (Owner, Firm 16)

\section{Geographic Isolation}

Our findings suggest that suppliers engage in CSR without being subject to their network's demand for collective behaviour when suppliers are positioned in geographically isolated zones with no other factories in the vicinity. Three of the four (75\%) geographically isolated suppliers interviewed emphasized their liberty of decision-making, including on CSR engagement. Their justification was the lack of shared workers and boundaries with other apparel factories. Table 6 lists six quotes from suppliers 
Table 6 Quotes illustrating that suppliers can engage in CSR when geographically isolated

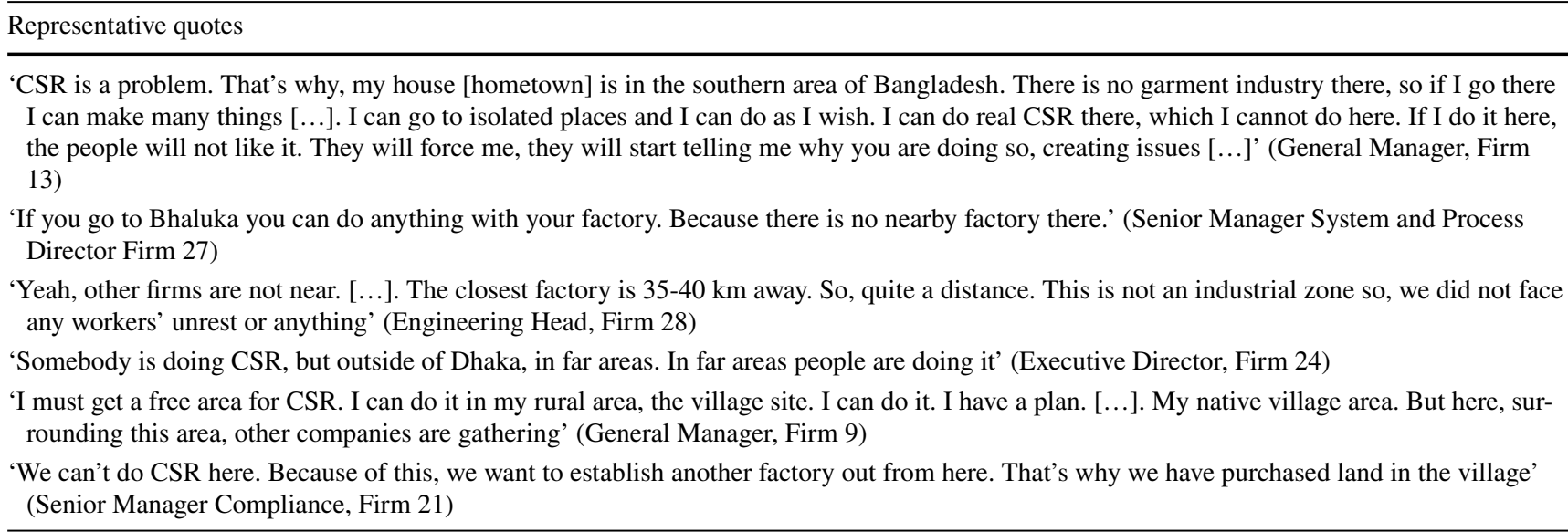

acknowledging freedom of decision-making in cases of geographic isolation.

However, geographic isolation was also identified as troublesome. In fact, being next to other apparel factories provides an array of advantages for suppliers (e.g. Knorringa and Nadvi 2016). Although geographic isolation increases suppliers' freedom of decision-making, collective behaviour and proximity to others guarantees support on a variety of problems, including but not limited to labour issues. These findings imply that working autonomously in geographically isolated areas leads to operational challenges. These include resource acquisition, ranging from securing and training a workforce to gaining access to power sources (e.g. gas and electricity).

\section{Size and Competitive Differentiation}

Size emerged as a relevant discriminant variable for CSR engagement. As shown in Table 3, larger size suppliers in Bangladesh are somewhat more prone to engaging in CSR officially. One reason for this is their understanding of CSR as a competitive advantage in the market. These findings reflect a dichotomy between larger and smaller factories in their view of CSR engagement. Only 3 (30\%) of suppliers with less than 1,000 employees saw CSR engagement as strategic. In contrast, 5 factories $(80 \%)$ with more than 5,000 employees interpreted CSR engagement as a strategic opportunity. Overall 14 (46.6\%) understood CSR engagement as an opportunity for competitive differentiation visà-vis labour and buyers. However, our findings also indicate the existence of a hierarchical, size-driven power asymmetry among network suppliers, with larger suppliers having ampler freedom and voice in deciding for the network, often holding political influence in the BGMEA and/or BKMEA. By engaging in CSR unilaterally, larger suppliers indirectly force their surrounding peers to apply homogeneous guidelines to avoid turbulence, spreading CSR engagement. In contrast, smaller suppliers avoid unilateral CSR engagement due to their low position in the hierarchy. As expressed by three executives:

His factory is huge. Some of the factories are engaging in CSR. However, in a new [small] factory that just started, nobody would dare to do that (Executive Director, Firm 24)

We are the biggest and they [other factories] cannot exert any pressure on us (Deputy General Manager Marketing and Merchandising, Firm 22)

When we started the factory we were small, we only had 2 stories. At that time we gave all the people free lunches. Complimentary from the management, free, nothing to pay. But in the other factories they didn't do it. Then they [other suppliers' owners] complained to the district office [...]. After that the father of the district called me. He said, you are doing that, fine. Nobody else is doing that. That is a problem for the area. You think about it and how to solve it. I said, we are happy, this is novel. He said, fine, but nobody else can give it. Then I told my workers that I couldn't give them food anymore (Owner, Firm 16)

Interestingly, our findings also show that larger suppliers' coercing of CSR engagement along the network causes tension between (1) aligning to the collective behaviour of the network to secure cooperation and social relationships and (2) engaging in CSR to gain competitive differentiation with buyers and labour.

One implication of this tension is fear and reluctance toward unilateral CSR engagement, which drives larger suppliers to move toward CSR while also seeking alternative solutions for its eventual impact. This is well elucidated by the quote below. 
Table 7 Quotes demonstrating that CSR engagement is possible through external pressures

Representative quotes

'We are scared of CSR. We are doing it but the rest of the factories is not doing it. We will have big problems so, we are requesting [the buyer] to start their [same] CSR activities. Slowly we will definitely continue. Because most of the surrounding factories are doing work with our same buyer'

(Executive Director Operation and Corporate Shareholder, Firm 17)

'When he became president, in his factory workers stopped working, and they tried to force him to increase salaries. The motive behind is that if the president of the BGMEA increases the salaries in his factory, then everybody else [other apparel suppliers] will have to do it' (Executive Director, Firm 24)

They [an international buying firm] said, I want to raise salaries to the workers of my factories [...]. I said, if you want it to start from your factories, it needs to start as a whole, with everybody. Otherwise they will be fighting. So now, of course, [an international buying firm] is starting, but slowly. Everything is possible, but you need to discuss [...]. It's good what they are doing now, they are involving the BGMEA and BKMEA' (Owner, Firm 27)

If you are big, you do CSR and then the others have to adjust to you. So, the people would not be happy. I mean, my people, the business community, would not be happy. And we should think about it as well [...]. What we do, if this impacts other people in a bad way, then I should not do it. I need to look up for my workers, but also need to look up for my other factory owners as well. These are also my colleagues (Executive Director, Firm 24)

\section{External Pressure}

Our findings show that suppliers engage in CSR in Bangladesh when driven by buyers and/or industry associations (BGMEA and/or BKMEA). Twenty-one suppliers (70\%) asserted that buyers have a strong impact on CSR engagement. Some particularly large international buyers in Bangladesh are now encouraging CSR engagement in exchange for volume-based incentives, as described in the quote below.

Since we have a score now [for CSR activities], we are bringing CSR to a more organised level. We did it before, but not in written documents, no evidence was kept. Ok, some workers came with some application. We gave them some money, with some local work representative $[\ldots]$. Now we are keeping the documents [...]. I am keeping everything documented so that I can show it to the buyers (General Manager Administration and Compliance, Firm 23)

Due to collective behaviour among suppliers, our evidence shows that buyers, BGMEA and/or BKMEA need to ensure that labour practices are applied homogeneously among suppliers that are in proximity to each other. To avoid conflict, however, all suppliers in the sample who engage in CSR officially also revealed that (1) their buyers have an interest in their CSR and (2) they are surrounded or nearby other suppliers who have relationships with the same buyers and therefore receive the same demands and incentives to engage in CSR. This increases suppliers' belief that their network will not be damaged because of CSR. Table 7 shows three additional quotes on CSR driven by external pressure.

\section{Discussion}

Our paper extends the scrutiny of CSR engagement in the GVC literature by detailing an in-depth and horizontal study of suppliers' collective behaviour on CSR engagement in the Bangladeshi apparel industry. We attempted to convey a new starting point by arguing for the usefulness of integrating an inter-organizational network lens to understand the horizontal implications of the supplier network on CSR engagement, in line with Santana et al. (2009). We find that collective behaviour limits unilateral CSR engagement, leading to significant implications for the role of business in society. This exploratory framework encompasses four scenarios of current suppliers' CSR engagement in developing countries, including their implications. In this section, we revisit our findings while expanding on the theoretical background presented earlier.

\section{Suppliers' Collective Behaviour on CSR Engagement}

Our first contribution and answer to our first research question reveals novel insights on suppliers' collective behaviour and their effect on CSR engagement in GVCs. We show that behavioural heterogeneity links to turbulence and instability among local players, in line with organizational scholars (e.g. Astley and Fombrun 1983). To recapitulate, we show that export-oriented, first-tier suppliers in developing countries are part of a horizontal network. As network constituents, they foster collective behaviour and cooperate against unilateral CSR engagement, interpreted as an exogenous threat because of the resulting heterogeneity of labour practices, resulting in worker unrest. This confirms the Melé (2009) argument that not adhering to the network's collective behaviour of inter-party exchange creates imbalance; all 
constituents' participation is required, and CSR engagement can be achieved when executed collectively. Our evidence holds two main implications.

First, the vertical focus in the GVC literature that assumes that CSR engagement is 'driven' by buyers to suppliers (Fernandez-Stark et al. 2011; Gereffi 1994; Ponte and Gibbon 2006) is conceptually myopic. Our findings show that this ignores the collective and horizontal dynamics existing among local business players and only partially explains their decision-making on practices such as CSR. Perhaps this also provides some justification for the poor results on buyer-driven CSR engagement (Lund-Thomsen and Lindgreen 2014). Our findings thus extend the Lund-Thomsen and Coe (2015) and Niforou (2015) claim about horizontal analysis in GVCs, showing that supplier networks can be specifically used as vehicles to study how the horizontal dimension influences CSR engagement.

Second, our study demonstrates that supplier networks represent a shared resource for social protection. Extending the understanding of collective behaviour in GVCs resulting from geographic density (Knorringa and Nadvi 2016) and awareness through information exchange (Rabellotti 1999), our study delineates this behaviour as a social control mechanism against external threats and political instability. Undoubtedly, GVCs in the developing world resemble difficult environments, characterized by limited statehood and buyers that ravage the market with bottom-line prices, as demonstrated by Anner (2015) and Fontana (2017). Specifically in Bangladesh, media attacks on suppliers, third-party inspections and buyers' imposition of private regulations following Rana Plaza (Accord 2016a) have reinforced supplier solidarity with each other. Collective behaviour on CSR engagement is ensured through normative pressure, information gained through direct and indirect communication, and acts as a self-established social control mechanism to ensure network stability. This also conforms with the Schmitz and Nadvi (1999) and Börzel and Risse (2010) arguments that social relationships replace other forms of governance, adding that collective behaviour is stronger the higher are the perceived threats from the external environment, as in the case of CSR.

\section{Supplier CSR Engagement in GVCs}

Our second contribution to the GVC literature and answer to our second research question goes to the understanding of CSR engagement in GVCs; we synthetize this in three discussion points.

First, our findings demonstrate that most suppliers act in support of their workers by engaging in CSR unofficially. While it is difficult to fully assess the extent of unofficial CSR engagement, as noted by Jamali et al. (2009) and Williams and Zinkin (2009) on the dichotomy between religious claims and practice, we observed a strong human dimension among suppliers' top managers. This manifests as social, discretionary and philanthropic proactivity, inhering in cultural and religious beliefs often unaccounted for or understated in the literature.

Second, we reveal that the effect of suppliers' collective behaviour on CSR engagement is geographic. The issue of network density put forth by organizational scholars (Borgatti and Foster 2003) dovetails well with supplier network in developing countries. We observe, in practice, that the influence on supplier CSR engagement is amplified the closer suppliers are to each other. On the contrary, it dissipates with distance. This finding is in line with the Gereffi et al. (2005) argument of geographic proximity as a source of frequent interactions and leads to two implications.

Isolated suppliers are less subject to their network's normative pressure, and their CSR engagement has limited effect on others. Although increased distance from others also leads to operational challenges due to less sharable resources (e.g. Davies 2009; Knorringa and Nadvi 2016), CSR engagement can be more easily achieved, for instance in rural areas, where corporate density is low. Given the operational difficulties in operating in geographically isolated areas though, this raises an additional question: how much do firms value freedom in exchange for their peers' social support? We believe that the answer lies in the tradeoff between the long-term advantages of decisional autonomy, including CSR, and the disadvantages of giving up the network's support. Currently, the quest for freedom in decision-making materializes in what Schmitz and Nadvi (1999) refer to as clusterization of supplier networks, to which we add the importance of size. More generally, we note in Bangladesh that larger suppliers tend to group next to each other, but at a distance from smaller ones. Likewise, the areas where smaller suppliers are located rarely include larger firms.

Arguably, this limits the turbulent effect of firm CSR engagement on the network and allows us to reformulate the Mezzadri (2014) claim that suppliers in different regions or areas are part of the same and unique network, with geographic isolation weakening their mutual influence. Concomitantly, it can then be theorized that the supplier network is composed of several industrial areas or clusters, and that the network allows different types of CSR engagement in each area, so long as homogeneous types of CSR are implemented in a given area.

Third, we provide an evaluation of the effect of corporate size on the limits of market-driven CSR. Larger suppliers understand CSR engagement in competitive terms and engage in it officially, clashing with the network's collective behaviour. Differently from the Acquier et al. (2017) CSR cost model, we note that tension lies between the market pressure to engage in CSR for competitiveness against social 
pressure from the network to cooperate without engaging in CSR unilaterally. Most larger suppliers in our study claimed to somehow 'fear' the effect of their CSR, referring to their business network as their 'business community'. The latter, which we more generally label here as a network, adheres to the Jamali and Mirshak (2007) description of shared environment, in which constituents' legitimacy and credibility hold particular relevance as social players. By doing so, we advance the Neilson and Pritchard (2010) argument that smaller manufacturers in developing countries depend on their social circle for support, showing the importance assigned to it by smaller and larger suppliers alike.

\section{Suggestions for Practice and Research}

We conclude that what is neglected in the literature and what suppliers find problematic is not CSR engagement per se, but its ad hoc and heterogeneous execution. Direct and indirect communication (e.g. workers' word-of-mouth) makes engaging in CSR difficult to conceal. Our recommendations, therefore, stress the need to ensure CSR integrity among all network constituents.

From a practical standpoint, we believe that there is a critical need for wider circulation of CSR information. This includes spreading awareness of the implications of CSR engagement. We note that rejection of CSR engagement is driven by misconceptions about its positive effect for firms and labour alike. This is exacerbated in Bangladesh, perhaps, by the confusion caused by the vertical imposition of different buyers' private regulations. In our view, it is imperative to make a more convincing argument in favour of CSR engagement. Suppliers need not only to be persuaded, but also convinced about CSR's benefits. This can be achieved by educating them and spreading information on CSR engagement homogeneously along the network, including a wider number of corporate participants, horizontally. More seminars, presentations, round-tables and wider discussions on the topic of CSR among suppliers are necessary. These are currently held by a very small number of particularly large buyers and address only a few participants, typically larger suppliers. One approach is to have buyers work more closely with industrial organizations, such as BGMEA and BKMEA in Bangladesh, and create a collective understanding of how CSR engagement can be informed on a larger scale. This would also serve as potent tool to avoid tension and political conflicts in the future.

In addition, we highlight the need to reconceptualize and extend the CSR paradigm to allow its applicability in developing countries. Undoubtedly, engaging in CSR remains extremely important to improve labour conditions in GVCs. Even if most doubts cast on the limits of CSR engagement pertain to its avoidance and voluntary nature (e.g. LundThomsen and Lindgreen 2014; Soundararajan and Brown
2016), we see a lack of understanding from international buyers and scholars on contextual contingencies. Arguably, the lack of CSR engagement cannot be ascribed merely to cost-saving (see Merk (2014)) or local managers' personal inclination toward their workers. We must consider the network effects which may limit CSR engagement as well.

As currently formulated, CSR represents a largely onesize-fits-all concept anchored in Anglo-Saxon traditions. Our findings show that, suppliers in developing countries are embedded in a context of opposite traditions and sociocultural variables that must be considered if CSR is to find local credence. Our findings thus agree with the Jamali and Karam (2016) assumption that CSR in the developing world is 'hybrid' in the way it is perceived and engaged, and must be treated distinctively. While current labour conditions in GVCs often are loathsome and unacceptable and claim that strengthening supplier decision-making would worsen them (e.g. Hoejmose et al. 2013), along with assumptions that suppliers aim to exploit workers (e.g. Rahim 2017), are widespread, a more critical analysis is perhaps needed. Our study poses a counter-argument, positing that in developing countries (1) horizontal dynamics shape supplier behaviour vis-à-vis CSR engagement and (2) a strong philanthropic sense persists among local suppliers. Both these factors are often understated, and we strongly recommend their concurrent consideration when studying CSR engagement.

\section{Conclusion, Limitations and Avenues for Future Research}

Local suppliers are central to developing countries' economic development, but also to the provision of social benefits (Naeem and Welford 2009; Welford and Frost 2006). Our study represents a novel attempt to show how suppliers' horizontal influence on each other shapes their CSR engagement. Based on a study of first-tier, export-oriented apparel suppliers in Bangladesh, we demonstrate that suppliers belong to a network, in which collective behaviour and cooperation prevents unilateral engagement in CSR.

The term non sibi, sed omibus (e.g., not for one's self but for all) has been adopted to emphasize semantically the role of collective behaviour with regard to CSR engagement.

While this is rooted in the need to establish long lasting relationships, collective behaviour also finds its justification in the need to avoid worker unrest and boycotts, that is, network instability as theorized by organizational scholarship (Astley and Fombrun 1983; Melé 2009).

As such, collective behaviour drives alignment to homogeneous labour practices and is maintained through normative pressures in the network. In turn, it is fuelled by the information shared through direct and indirect communication, making supplier vulnerable to each other. 
However, we also identify various scenarios and drivers of CSR engagement. These range from engaging in CSR unofficially and in isolation, to imposing CSR on the network due to size and, ultimately, by acquiescing to buyers and trade associations.

By building on the Santana et al. (2009) argument that integrating an inter-organizational network lens can be useful for the examination of CSR engagement, we highlight the theoretical importance to develop an alternative to the conventional focus of GVCs on vertical chain (e.g. FernandezStark et al. 2011; Ponte and Gibbon 2006), while stressing the pivotal role of suppliers in improving labour conditions in GVCs.

In so doing, we address a gap in the literature (Yawar and Seuring 2017), and hope to stimulate further research into supplier horizontal and collective behaviour in GVCs.

Our study has limitations that hold implications for future inquiries. It focuses entirely on first-tier suppliers in GVCs. This is justified by our interest in observe the effect of horizontal relationships among players of the same type and their links to buyers. However, we believe that broadening the focus upstream to examine the relationships among different types of suppliers (e.g. second-tier and third-tier suppliers) may reveal opposite influences and tensions, perhaps providing valuable insight into this field of study. Similarly, additional interviews executed with different stakeholders, including workers, should be implemented to prove the veracity of supplier claims.

Further, our study focuses exclusively on apparel suppliers in Bangladesh. However, Bangladesh is a developing country particularly suited to the study of CSR engagement in GVCs. Although we believe that our results provide analytical generalization, replication of this study in (1) different sociocultural and economic contexts and (2) non-apparel industries, may reveal new elements that might enrich or even pose productive counterarguments to our findings. Analogously, such work could also provide additional evidence to the notion of geographic isolation, demonstrating the existence of other relevant contextual variables.

Additionally, our study is based on interviews conducted with suppliers' top managers, given their relevant role as CSR decision makers (Park and Stoel 2005). However, we do not aim to measure managers' personal and individual attributes, but rather to obtain their corporate opinion. We are convinced that more systematic attention to the microdimension of GVCs would benefit the field. This includes, for instance, the presence of cognitive, empathic and emotional antecedents of CSR engagement. As shown by Niforou (2015) and Jamali and Karam (2016), there is a shortage of research at the individual level of analysis in developing countries. Uncovering respondents' personal histories, inclinations and beliefs might help explicate the dichotomy highlighted by Williams and Zinkin (2009) pertaining to religious claims and practices in developing countries, but also add new insights on the personal interpretation and meaning attributed to CSR engagement.

Finally, our study follows a qualitative trajectory. Elaborating on mixed-methods, such as by including a survey run on suppliers, as shown by Jayasinghe (2016), may reinforce understanding of horizontal relationships in GVCs. While this might limit the depth of results, it could broaden their external validity. Despite the challenge of retrieving data in developing countries, respondent-driven sampling could be used to reach a wider array of respondents. As suggested by Brammer et al. (2011), a wider sample could also be obtained by seeking more unorthodox solutions, such as including practitioners from the field who can open up avenues to wider data collection.

\section{Compliance with Ethical Standards}

Conflicts of interest The authors declare that they have no conflict of interests.

Ethical Approval All procedures performed in studies involving human participants were in accordance with the ethical standards of the institutional and/or national research committee and with the 1964 Helsinki declaration and its later amendments or comparable ethical standards.

Informed Consent Informed consent was obtained from all individual participants included in the study.

Open Access This article is distributed under the terms of the Creative Commons Attribution 4.0 International License (http://creativeco mmons.org/licenses/by/4.0/), which permits unrestricted use, distribution, and reproduction in any medium, provided you give appropriate credit to the original author(s) and the source, provide a link to the Creative Commons license, and indicate if changes were made.

\section{References}

Accord. (2016a). About the accord on fire and building safety in Bangladesh. Retrieved from http://bangladeshaccord.org/about/

Accord. (2016b). List of factories. Retrieved from http://bangladesh accord.org/wp-content/uploads/Accord-Public-Disclosure-Repor t-1-November-2016.pdf

Acquier, A., Valiorgue, B., \& Daudigeos, T. (2017). Sharing the shared value: A transaction cost perspective on strategic CSR policies in global value chains. Journal of Business Ethics, 144(1), 139-152.

Angrosino, M., \& Rosenberg, J. (2011). Observations on observations. In N. K. Denzin \& Y. Lincoln (Eds.), Collecting and interpreting qualitative materials (4th ed., pp. 151-175). London: Sage.

Anner, M. (2015). Labor control regimes and worker resistance in global supply chains. Labor History, 56(3), 292-307.

Aßländer, M. S., Roloff, J., \& Nayır, D. Z. (2016). Suppliers as stewards? Managing social standards in first- and second-tier suppliers. Journal of Business Ethics, 139(4), 661-683.

Astley, W. G., \& Fombrun, C. J. (1983). Collective strategy: Social ecology of organizational environments. Academy of Management Review, 8(4), 576-587. 
Bansal, P., \& Roth, K. (2000). Why companies go green: A model of ecological responsiveness. Academy of Management Journal, 43(4), 717-736.

Belal, A. R., \& Roberts, R. W. (2010). Stakeholders' perceptions of corporate social reporting in Bangladesh. Journal of Business Ethics, 97(2), 311-324.

Berg, A., Berlemann, B., \& Hedrich, S. (2013). The global sourcing map. Retrieved from http://www.bgcci.com/publication/mckin sey-apparel-cpo-survey-2013/

Berg, A., Hedrich, S., Kempf, S., \& Tochtermann, T. (2011). Bangladesh's ready-made garments landscape: The challenge of growth. Retrieved from http://www.mckinsey.de/sites/mck_files/files /2011_McKinsey_Bangladesh.pdf

BGMEA. (2016a). About garment industry of Bangladesh. Retrieved from http://www.bgmea.com.bd/home/about/AboutGarmentsIn dustry

BGMEA. (2016b). BGMEA at a Glance. Retrieved from http://www. bgmea.com.bd/home/about

BKMEA. (2016). BKMEA: An innovative and creative organization. Retrieved from http://www.bkmea.com/BKMEA-at-a-glance.html

Bluhm, D. J., Harman, W., Lee, T. W., \& Mitchell, T. R. (2011). Qualitative research in management: A decade of progress. Journal of Management Studies, 48(8), 1866-1891.

Borgatti, S. P., \& Foster, P. C. (2003). The network paradigm in organizational research: A review and typology. Journal of Management, 29(6), 991-1013.

Börzel, T. A., \& Risse, T. (2010). Governance without a state: Can it work? Regulation \& Governance, 4(2), 113-134.

Brammer, S., Hoejmose, S. U., \& Millington, A. (2011). Managing sustainable global supply chains. A systematic review of the body of knowledge. Network for Business Sustainability. Retrieved from http://nbs.net/wp-content/uploads/NBS-Systematic-Review-Suppl y-Chains.pdf

CIA. (2016). South Asia: Bangladesh. Retrieved from https://www.cia. gov/library/publications/the-world-factbook/geos/bg.html

Cialdini, R. B., \& Trost, M. R. (1998). Social influence: Social norms, conformity, and compliance. In D. T. Gilbert, S. T. Fiske, \& G. Lindzey (Eds.), The handbook of social psychology (4th ed., pp. 151-192). New York: McGraw-Hill.

Coleman, J. S. (1988). Social capital in the creation of human capital. American Journal of Sociology, 94, S95-S120.

Daboub, A. J., \& Calton, J. M. (2002). Stakeholder learning dialogues: How to preserve ethical responsibility in networks. Journal of Business Ethics, 41(1/2), 85-98.

Davies, I. A. (2009). Alliances and networks: Creating success in the UK fair trade market. Journal of Business Ethics, 86(1), 109-126.

Eisenhardt, K. M. (1989). Bulding theories from case study research. Academy of Management Review, 14(4), 532-550.

Eisenhardt, K. M., Graebner, M. E., \& Sonenshein, S. (2016). Grand challenges and inductive methods: Rigor without rigor mortis. Academy of Management Journal, 59(4), 1113-1123.

Elg, U., \& Johansson, U. (1997). Decision making in inter-firm networks as a political process. Organization Studies, 18(3), 361-384.

Fernandez-Stark, K., Frederick, S., \& Gereffi, G. (2011). The apparel global value chain (pp. 1-62). Governance and Competitiveness: Duke Center on Globalization.

Foerstl, K., Azadegan, A., Leppelt, T., \& Hartmann, E. (2015). Drivers of supplier sustainability: Moving beyond compliance to commitment. Journal of Supply Chain Management, 51(1), 67-92.

Fontana, E. (2017). Strategic CSR: A panacea for profit and altruism? An empirical study among executives in the Bangladeshi RMG supply chain. European Business Review, 29(3), 304-319.

Frost, P. J., \& Egri, C. P. (1991). The political process of innovation. Research in Organizational Behavior, 13, 229-295.
Gereffi, G. (1994). The organization of buyer-driven global commodity chains: How US retailers shape overseas production networks. In G. Gereffi \& M. Korzeniewicz (Eds.), Commodity chains and global capitalism (pp. 95-122). Westport, CT: Praeger.

Gereffi, G., Humphrey, J., \& Sturgeon, T. J. (2005). The governance of global value chains. Review of International Political Economy, 12(1), 78-104.

Gereffi, G., \& Lee, J. (2016). Economic and social upgrading in global value chains and industrial clusters: Why governance matters. Journal of Business Ethics, 133(1), 25-38.

Gioia, D. A., Corley, K. G., \& Hamilton, A. L. (2013). Seeking qualitative rigor in inductive research: Notes on the Gioia methodology. Organizational Research Methods, 16(1), 15-31.

Giuliani, E. (2016). Human rights and corporate social responsibility in developing countries' industrial clusters. Journal of Business Ethics, 133(1), 39-54.

Gould, R. V. (1993). Collective action and network structure. American Sociological Review, 58(2), 182-196.

Granovetter, M. S. (1985). Economic action and social structure: The problem of embeddedness. American Journal of Sociology, 91(3), 481-510.

Greening, D. W., \& Turban, D. B. (2000). Corporate social performance as a competitive advantage in attracting a quality workforce. Business and Society, 39(3), 254-280.

Håkansson, H., \& Johanson, J. (1988). Formal and informal cooperation strategies in international industrial networks. In F. J. Contractor \& P. Lorange (Eds), Cooperative strategies in international business (pp. 369-379). MA: Lexington Books.

Hoejmose, S. U., Grosvold, J., \& Millington, A. (2013). Socially responsible supply chains: Power asymmetries and joint dependence. Supply Chain Management: An International Journal, 18(3), 277-291.

Hoejmose, S. U., Roehrich, J. K., \& Grosvold, J. (2014). Is doing more doing better? The relationship between responsible supply chain management and corporate reputation. Industrial Marketing Management, 43(1), 77-90.

Huq, A. F., Stevenson, M., \& Zorzini, M. (2014). Social sustainability in developing country suppliers: An exploratory study in the ready made garments industry of Bangladesh. International Journal of Operations \& Production Management, 34(5), 610-638.

ILO. (2015a). Labor standards. Retrieved from http://www.ilo.org/ global/standards/lang-en/index.htm

ILO. (2015b). Textiles, clothing, leather and footwear sector. Retrieved from http://www.ilo.org/global/industries-and-sectors/textilesclothing-leather-footwear/lang-en/index.htm

Islam, M. A., \& Deegan, C. (2008). Motivations for an organisation within a developing country to report social responsibility information: Evidence from Bangladesh. Accounting, Auditing \& Accountability Journal, 21(6), 850-874.

Jamali, D. (2007). The case for strategic corporate social responsibility in developing countries. Business and Society Review, 112(1), $1-27$.

Jamali, D., \& Karam, C. M. (2016). Corporate social responsibility in developing countries as an emerging field of study. International Journal of Management Reviews. https://doi.org/10.1111/ ijmr.12112.

Jamali, D., \& Mirshak, R. (2007). Corporate social responsibility (CSR): Theory and practice in a developing country context. Journal of Business Ethics, 72(3), 243-262.

Jamali, D., Zanhour, M., \& Keshishian, T. (2009). Peculiar strengths and relational attributes of SMEs in the context of CSR. Journal of Business Ethics, 87(3), 355-377.

Jayasinghe, M. (2016). The operational and signaling benefits of voluntary labor code adoption: Reconceptualizing the scope of human 
resource management in emerging economies. Academy of Management Journal, 59(2), 658-677.

Knorringa, P., \& Nadvi, K. (2016). Rising power clusters and the challenges of local and global standards. Journal of Business Ethics, 133(1), 55-72.

Labowitz, S., \& Baumann-Pauly, D. (2015). Beyond the tip of the iceberg: Bangladesh's forgotten apparel workers. New York. Retrieved from http://people.stern.nyu.edu/twadhwa/bangladesh /downloads/beyond_the_tip_of_the_iceberg_report.pdf

Liedtka, J. M. (1992). Exploring ethical issues using personal interviews. Business Ethics Quarterly, 2(2), 161-181.

Lund-Thomsen, P., \& Coe, N. M. (2015). Corporate social responsibility and labour agency: The case of Nike in Pakistan. Journal of Economic Geography, 15(2), 275-296.

Lund-Thomsen, P., \& Lindgreen, A. (2014). Corporate social responsibility in global value chains: Where are we now and where are we going? Journal of Business Ethics, 123(1), 11-22.

Lund-Thomsen, P., Lindgreen, A., \& Vanhamme, J. (2016). Industrial clusters and corporate social responsibility in developing countries: What we know, what we do not know, and what we need to know. Journal of Business Ethics, 133(1), 9-24.

Lund-Thomsen, P., \& Nadvi, K. (2010). Clusters, chains and compliance: Corporate social responsibility and governance in football manufacturing in South Asia. Journal of Business Ethics, 93(2), 201-222.

Mair, J., Martí, I., \& Ventresca, M. J. (2012). Building inclusive markets in rural Bangladesh: How intermediaries work institutional voids. Academy of Management Journal, 55(4), 819-850.

Marwell, G., Oliver, P. E., \& Prahl, R. (1988). Social networks and collective action: A theory of the critical mass. III. American Journal of Sociology, 94(3), 502-534.

McWilliams, A., \& Siegel, D. S. (2001). Corporate social responsibility: A theory of the firm perspective. Academy of Management Review, 26(1), 117-127.

Melé, D. (2009). The practice of networking: An ethical approach. Journal of Business Ethics, 90(Supplement 4), 487-503.

Merk, J. (2014). The rise of tier 1 firms in the global garment industry: Challenges for labour rights advocates. Oxford Development Studies, 42(2), 277-295.

Mezzadri, A. (2014). Indian garment clusters and CSR norms: Incompatible agendas at the bottom of the garment commodity chain. Oxford Development Studies, 42(2), 217-237.

Millar, C. C. J. M., \& Choi, C. J. (2009). Networks, social norms and knowledge sub-networks. Journal of Business Ethics, 90(Supplement 4), 565-574.

Munksgaard, K. B., \& Medlin, C. J. (2014). Self-and collectiveinterests: Using formal network activities for developing firms' business. Industrial Marketing Management, 43(4), 613-621.

Muthuri, J. N., Chapple, W., \& Moon, J. (2009). An integrated approach to implementing community participation in corporate community involvement: Lessons from Magadi Soda Company in Kenya. Journal of Business Ethics, 85(2), 431-444.

Nadvi, K. (1999). Collective efficiency and collective failure: The response of the Sialkot surgical instrument cluster to global quality pressures. World Development, 27(9), 1605-1626.

Naeem, M. A., \& Welford, R. (2009). A comparative study of corporate social responsibility in Bangladesh and Pakistan. Corporate Social Responsibility and Environmental Management, 16(2), 2009.

Needham, S. (2015). Garment worker's rights and voice in Bangladesh given boost. Retrieved December 4, 2015, from http:// www.ilo.org/newyork/news/WCMS_408360/lang-en/index.htm

Neilson, J., \& Pritchard, B. (2010). Fairness and ethicality in their place: The regional dynamics of fair trade and ethical sourcing agendas in the plantation districts of South India. Environment and Planning A, 42(8), 1833-1851.
Neville, B. A., \& Menguc, B. (2006). Stakeholder multiplicity: Toward an understanding of the interactions between stakeholders. Journal of Business Ethics, 66(4), 377-391.

Niforou, C. (2015). Labour leverage in global value chains: The role of interdependencies and multi-level dynamics. Journal of Business Ethics, 130(2), 301-311.

Pagell, M., \& Wu, Z. (2009). Building a more complete theory on sustainable supply chain management using case studies from 10 exemplars. Journal of Supply Chain Management, 45(2), $37-56$.

Park, H., \& Stoel, L. (2005). A model of socially responsible buying/ sourcing decision-making processes. International Journal of Retail and Distribution Management, 33(4), 235-248.

Perez-Batres, L. A., Doh, J. P., Miller, V. V., \& Pisani, M. J. (2012). Stakeholder pressures as determinants of CSR strategic choice: Why do firms choose symbolic versus substantive self-regulatory codes of conduct? Journal of Business Ethics, 110(2), 157-172.

Ponte, S., \& Gibbon, P. (2006). Quality standards, conventions and the governance of global value chains. Economy and Society, $34(1), 1-31$

Posthuma, A., \& Nathan, D. (2010). Labor in global production networks in India. New Delhi: Oxford University Press.

Rabellotti, R. (1999). Recovery of a Mexican cluster: Devaluation bonanza or collective efficiency? World Development, 27(9), $1571-1585$.

Rahim, M. M. (2017). Improving social responsibility in RMG industries through a new governance approach in laws. Journal of Business Ethics, 143(4), 807-826.

Rahim, M. M., \& Alam, S. (2014). Convergence of corporate social responsibility and corporate governance in weak economies: The case of Bangladesh. Journal of Business Ethics, 124(4), 607-620.

Reed, D. (2002). Employing normative stakeholder theory in developing countries. Business and Society, 2(41), 166-207.

Ritchie, J., Lewis, J., Nicholls, C. M., \& Ormston, R. (2013). Qualitative research practice: A guide for social science students and researchers (2nd ed.). London: Sage.

Roberts, S. (2003). Supply chain specific? Understanding the patchy success of ethical sourcing initiatives. Journal of Business Ethics, 44(2/3), 159-170.

Santana, A., Vaccaro, A., \& Wood, D. J. (2009). Ethics and the networked business. Journal of Business Ethics, 90(Supplement 4), 661-681.

Schmitz, H. (1999). Global competition and local cooperation: Success and failure in the Sinos Valley, Brazil. World Development, 27(9), 1627-1650.

Schmitz, H., \& Nadvi, K. (1999). Clustering and industrialization: Introduction. World Development, 27(9), 1503-1514.

Sharmin, S., Khan, N. A., \& Belal, A. R. (2014). Corporate community involvement in Bangladesh: An empirical study. Corporate Social Responsibility and Environmental Management, 21(4), 41-51.

Siddiqui, J. (2010). Development of corporate governance regulations: The case of an emerging economy. Journal of Business Ethics, 91(2), 253-274.

Soundararajan, V., \& Brown, J. A. (2016). Voluntary governance mechanisms in global supply chains: Beyond CSR to a stakeholder utility perspective. Journal of Business Ethics, 134(1), 83-102.

Uddin, S., \& Choudhury, J. (2008). Rationality, traditionalism and the state of corporate governance mechanisms: Illustrations from a less-developed country. Accounting, Auditing \& Accountability Journal, 21(7), 1026-1051. 
UNDP. (2015). Human development report. New York. Retrieved from http://hdr.undp.org/sites/default/files/2015_human_devel opment_report.pdf

Visser, W. (2008). Corporate social responsibility in developing countries. In C. A. McWilliams, D. Matten, J. Moon, \& D. Siegels (Eds.), Oxford handbook of corporate social responsibility (pp. 473-479). Oxford: Oxford University Press.

Welford, R., \& Frost, S. (2006). Corporate social responsibility in Asian supply chains. Corporate Social Responsibility and Environmental Management, 13(3), 166-176.
Williams, G., \& Zinkin, J. (2009). Islam and CSR: A study of the compatibility between the tenets of Islam and the UN Global Compact. Journal of Business Ethics, 91(4), 519-533.

Yawar, S. A., \& Seuring, S. (2017). Management of social issues in supply chains: A literature review exploring social issues, actions and performance outcomes. Journal of Business Ethics, 141(3), 621-643.

Zerbe, W. J., \& Paulhus, D. L. (1987). Socially desirable responding in organizational behavior: A reconception. Academy of Management Review, 12(2), 250-264. 